\title{
PENGARUH PEMBERIAN AUGMENTATIVE AND ALTERNATIVE COMMUNICATION (AAC) TERHADAP KEMAMPUAN FUNGSIONAL KOMUNIKASI DAN DEPRESI PASIEN AFASIA MOTORIK
}

\author{
Amila $^{1 *}$, Ratna Sitorus ${ }^{2}$, Tuti Herawati ${ }^{2}$ \\ 1. Program Studi Magister, Fakultas Ilmu Keperawatan, Universitas Indonesia, Depok 16424, Indonesia \\ 2. Fakultas Ilmu Keperawatan, Universitas Indonesia, Depok 16424, Indonesia \\ *E-mail: mila_difa@yahoo.co.id
}

\begin{abstract}
Abstrak
Afasia motorik merupakan salah satu gangguan komunikasi yang terjadi akibat stroke yang dapat menyebabkan gangguan kemampuan fungsional komunikasi dan depresi. Pasien dengan afasia motorik membutuhkan alat pengganti komunikatif yang efektif. Salah satu alat pengganti komunikasi adalah Augmentative and Alternatif Communication (ACC) yang merupakan alat komunikasi pengganti dengan menggunakan papan elektronik berupa gambar dan simbol. Penelitian ini bertujuan untuk mengetahui pengaruh pemberian AAC terhadap kemampuan fungsional komunikasi dan depresi pasien stroke dengan afasia motorik. Peneliti menggunakan desain quasi experiment post test non equivalent control group pada 21 responden yang terbagi menjadi 11 responden pada kelompok kontrol dan 10 responden pada kelompok intervensi. Hasil penelitian ini menunjukkan terdapat perbedaan yang bermakna rerata depresi antara kelompok kontrol dengan intervensi $(\mathrm{p}=0,542)$, namun terdapat perbedaan yang tidak bermakna rerata kemampuan fungsional antara kelompok kontrol dan intervensi $(\mathrm{p}=0,022)$. Hasil penelitian ini merekomendasikan AAC menjadi salah satu alternatif intervensi untuk memfasilitasi komunikasi, sehingga dapat menurunkan depresi pasien stroke dengan afasia motorik.
\end{abstract}

Kata kunci: afasia motorik, augmentative and alternative communication, depresi, stroke

\section{Abstract}

The Effect of Augmentative and Alternative Communication towards Depression and Communication Functional Ability of Patient with Motoric Aphasia. The purpose of this study was to determine the influence of conducting communication by AAC to the communication functional ability and depression for stroke patients with motor aphasia. The study design used was quasi experiment by approaching post test non equivalent control group for 21 respondents consist of 11 people of control group and 10 people of the intervention group. The results showed that no significant difference in the average communication functional ability between the control group and intervention group ( $p=$ $0,542)$, but there were significant differences between the average depression of control and intervention group ( $p=$ 0,022). Based on the results of study, the giving by AAC could be one of the nursing intervention for facilitating communication that will decrease depression to the stroke patient with motor aphasia.

Keywords: augmentative and alternative communication, depression, motoric aphasia, stroke

\section{Pendahuluan}

Stroke merupakan gangguan yang terjadi pada aliran darah khususnya aliran darah pada pembuluh arteri otak yang dapat menimbulkan gangguan neurologis. Di Indonesia, diperkirakan setiap tahun sekitar 500.000 penduduk terkena serangan stroke dan sekitar 125.000 orang meninggal dan sisanya mengalami cacat ringan atau berat (Yastroki, 2011).
Stroke dapat mengakibatkan manifestasi klinik yang beragam. Manifestasi yang timbul akibat stroke sangat tergantung pada luasnya area otak yang mengalami kerusakan dan jenis pembuluh darah atau area perfusi yang terganggu (Silbernagl \& Lang, 2007). Pembuluh darah yang sering mengalami gangguan pada pasien stroke adalah pembuluh darah arteri serebri media. Manifestasi yang timbul akibat gangguan pada arteri media adalah afasia. 
Afasia merupakan gangguan interpretasi dan formulasi simbol bahasa yang disebabkan oleh cedera otak atau proses patologik stroke, perdarahan otak, tumor otak pada lobus frontal, temporal atau parietal yang mengatur kemampuan berbahasa yaitu area Broca, area Wernicke dan jalur yang menghubungkan antara keduanya. Kedua area ini biasanya terletak di hemisfer kiri otak yang merupakan tempat kemampuan berbahasa (Price \& Wilson, 2006). Diperkirakan sekitar 21\%-35\% pasien stroke akut dapat mengalami afasia (Salter, Jutai, Foley, Hellings, \& Teasell, 2006).

Menurut Lumbantobing (2011) beberapa bentuk afasia mayor adalah afasia sensoris (Wernicke), motorik (Broca), dan Global. Afasia motorik terjadi akibat lesi pada area Broca di lobus frontal yang ditandai dengan kesulitan dalam mengkoordinasikan pikiran, perasaan dan kemauan menjadi simbol bermakna dan dimengerti oleh orang lain dalam bentuk ekspresi verbal dan tulisan.

Afasia memberikan dampak pada berbagai aspek kehidupan. Terutama pada kesejahteraan pasien, kemandirian, partisipasi sosial, dan kualitas hidup pasien. Dampak ini muncul diakibatkan komunikasi yang tidak adekuat antara pasien dan lingkungan. Kondisi mortilitas yang tinggi dan kemampuan fungsional yang rendah pada pasien afasia dapat terjadi karena pasien tidak mampu mengungkapkan apa yang pasien inginkan, tidak mampu menjawab pertanyaan atau berpartisipasi dalam percakapan. Ketidakmampuan ini menyebabkan pasien menjadi frustasi, marah, kehilangan harga diri, dan emosi pasien menjadi labil yang pada akhirnya dapat menyebabkan pasien menjadi depresi (Mulyatsih \& Ahmad, 2010).

Depresi paska stroke (DPS) merupakan gangguan mood yang dapat terjadi setiap waktu pada fase akut atau satu tahun paska stroke dengan puncaknya terjadi pada bulan pertama (Dahlin, et al., 2007). Menurut Amir (2005), frekuensi depresi lebih tinggi pada pasien afasia motorik daripada afasia global (71\%:44\%). Tingginya frekuensi depresi pada pasien afasia motorik disebabkan oleh tingginya kesadaran pasien akan ketidakmampuan yang dialami pasien. DPS memiliki efek negatif terhadap pemulihan fungsi kognitif, aktivitas hidup sehari-hari dan dapat meningkatkan kematian (Caiero, Ferro, Santos, \& Luis, 2006). Pasien akan menarik diri dari kegiatan sosial, menjadi rendah diri, dan rehabilitasi yang tidak optimal.

Hasil sistematik review yang dilakukan Poslawsky, Schuurmans, Lindeman, dan Hafstensdottir (2010), menjelaskan tentang kontribusi perawat dalam latihan wicara secara intensif yang dimulai pada fase akut menunjukkan hasil rehabilitasi yang terbaik terhadap fungsi berbahasa pasien afasia. Berdasarkan hasil tersebut, peran perawat untuk melatih wicara yang dimulai sejak fase akut sangat penting untuk tercapainya proses rehabilitasi yang optimal pada pasien afasia. Studi ini juga menjelaskan keterlibatan keluarga pada proses latihan juga dibutuhkan untuk memberikan dalam proses pemulihan bahasa dan pelaksanaan latihan komunikasi pasien, baik selama di rumah sakit ataupun di rumah. Studi ini sejalan dengan Bullan, Chiki, dan Stern (2007) yang menjelaskan pentingnya keterlibatan anggota keluarga dan teman dalam latihan untuk meningkatkan efektivitas rehabilitasi.

Gangguan komunikasi pada pasien afasia memerlukan intervensi keperawatan yang tepat. Beberapa alat bantu komunikasi yang dapat digunakan pada pasien afasia menurut Nursing Interventions Classification (NIC) adalah penggunaan perangkat elektronik, papan alfabet, papan gambar/ flash card yang berisi gambar kebutuhan dasar, stimulus visual, alat tulis, kata-kata yang sederhana, bahan yang berisi tulisan atau gambar yang dapat ditunjuk oleh pasien (Smeltzer, Bare, Hinkle, \& Cheever, 2010). Intervensi keperawatan tersebut merupakan bagian dari Augmentative and Alternatif Communication (AAC).

Menurut Johnson, Hough, King, Vos, dan Jeffs, (2008), AAC merupakan pengganti komunikasi verbal seseorang. AAC terdiri dari low technology dan high technology. AAC dengan low technology yaitu komunikasi tanpa menggunakan 
elektronik, seperti papan komunikasi yang berisi gambar/simbol dan tulisan berisi gambar. AAC yang menggunakan elektronik adalah high technology, seperti komputer. AAC memberikan keuntungan terhadap kemampuan bahasa dan berkomunikasi, meningkatkan kemandirian dan perkembangan hubungan sosial dan membantu perawat berkomunikasi dengan pasien yang mengalami keterbatasan komunikasi verbal (Clarkson, 2010).

Beberapa penelitian tentang manfaat pemberian latihan komunikasi terhadapkemampuanfungsional komunikasi diatas telah banyak dikembangkan oleh beberapa peneliti. Hasil penelitian oleh Bhogal, Teasell, Foley, dan Speechley (2003) yang menggunakan kartu gambar dalam latihan wicara pada afasia selama 30 jam selama 10 hari menunjukkan peningkatan kemampuan berbahasa, penamaan, dan pemahaman berbahasa yang dievaluasi dengan tes wicara (Token Test).

Hasil penelitian yang dilakukan oleh Bakheit, et al., (2007) yang menggunakan media gambar (orientasi tugas menyeleksi gambar, penamaan objek, menjelaskan, dan mengenalkan hubungan antara kedua item) pada 2 kelompok dengan durasi yang berbeda (5 jam dan 2 jam) selama 12 minggu, menunjukkan perbedaan yang bermakna terhadap kemampuan berbahasa pada kelompok standar dengan waktu 2 jam $(p=0,002)$ dibandingkan dengan kelompok intensif dengan waktu 5 jam ( $p>0,05)$.

Dari kedua penelitian terdapat berbagai variasi intensitas dan durasi latihan komunikasi, tetapi yang terpenting latihan harus dimulai sedini mungkin setelah melewati fase akut dan dalam kondisi stabil. Pendapat ini didukung oleh penelitian Bakheit, et al., (2007), latihan secara intensif dapat meningkatkan neuroplastisitas, reorganisasi peta kortikal dan meningkatkan fungsi motorik.

Berdasarkan hasil wawancara dengan perawat ruangan, selama ini penanganan pasien stroke yang mengalami afasia hanya berfokus pada penanganan fisik saja. Pemberian alat bantu komunikasi pada pasien afasia hanya diberikan isyarat atau alat tulis tanpa diberikan stimulasi latihan, sehingga tidak sepenuhnya mendukung pasien untuk memfasilitasi komunikasi dan meningkatkan komunikasi pasien selama di rumah sakit. Perawat juga tidak mengetahui kalau pasien mengalami afasia, karena tidak mendeteksi adanya afasia, sehingga latihan komunikasi terlambat/ tidak dilakukan. Keadaan ini akan memperlambat pola penyembuhan dan pasien akan mengalami depresi karena tidak mampu dalam berkomunikasi. Penelitian ini bertujuan mengetahui pengaruh pemberian AAC terhadap kemampuan fungsional komunikasi dan depresi pada pasien stroke dengan afasia motorik dengan mengidentifikasi perbedaan rerata kemampuan fungsional komunikasi dan depresi sesudah diberikan AAC.

\section{Metode}

Penelitian ini menggunakan desain penelitian quasi experiment dengan pendekatan post test non equivalent control group, dengan jumlah sampel 11 kontrol dan 10 intervensi yang ditetapkan dengan teknik consecutive sampling. Kriteria inklusi sampel antara lain: pasien yang didiagnosa stroke hemoragik dan non-hemoragik yang mengalami afasia motorik. Penentuan afasia motorik dibuat berdasarkan format Frenchay Aphasia Screening Test (FAST), kesadaran kompos mentis, pasien yang ditunggu oleh keluarganya dan terlibat dalam latihan komunikasi, pasien, dan keluarga bersedia menjadi responden. Sedangkan kriteria ekslusi meliputi pasien dengan disartria, mempunyai riwayat depresi sebelum stroke, pasien yang mendapat terapi antidepresan dan mengalami peningkatan tekanan intrakranial (adanya muntah proyektil, pusing, tekanan darah tidak stabil, penurunan kesadaran).

Proses pengumpulan data dilaksanakan di ruang neurologi di tiga RSUD di Jawa Barat. Latihan komunikasi dengan AAC dilakukan 3 kali sehari, yaitu pada pagi hari pukul 09.00, siang hari pukul 13.00 dan sore hari pukul 15.00 WIB dengan frekuensi waktu 30 menit. Latihan komunikasi juga melibatkan keluarga menggunakan pedoman kebutuhan aktivitas sehari-hari yang disusun oleh peneliti dengan tugas menyebutkan penamaan, 
pengulangan, membaca, mengeja, dan menulis dan dilakukan selama 90 menit. Total latihan ini 30 jam selama 10 hari. Waktu 30 jam selama 10 hari merupakan waktu yang pernah digunakan oleh Bhogal, et al., (2003) yang menggunakan constraint induced therapy (menggunakan kartu bergambar) dalam latihan wicara.

\section{Hasil}

Hasil analisis univariat mendapatkan data rerata umur responden adalah 62,10 tahun, dengan umur termuda 42 tahun dan tertua 76 tahun. Sebagian besar responden memiliki jenis kelamin laki-laki yaitu 13 orang $(61,90 \%)$. Distribusi karakteristik responden berdasarkan banyaknya jumlah serangan stroke menunjukkan bahwa dari 21 orang responden, sebagian besar responden memiliki jumlah serangan stroke 1 kali sebanyak 11 orang $(52,38 \%)$. Rerata ketidakmampuan fisik responden adalah 25,48 dengan ketidak-mampuan fisik terendah 10 dan tertinggi 40. Rerata dukungan keluarga responden adalah 46,48 dengan dukungan keluarga terendah 39 dan tertinggi 53. Rerata kemampuan fungsional komunikasi responden adalah 10,86 dengan kemampuan fungsional komunikasi terendah 8 dan tertinggi 14 . Analisis bivariat perbedaan kemampuan fungsional komunikasi dan depresi sesudah diberikan komunikasi dengan AAC digambarkan pada Tabel 1 dan Tabel 2.
Berdasarkan hasil analisis Tabel 1, didapatkan rerata kemampuan fungsional komunikasi responden kelompok kontrol adalah 10,64 dengan standar deviasi 1,748, sedangkan rerata kemampuan fungsional komunikasi responden kelompok intervensi adalah 11,10, dengan standar deviasi 1,663. Hasil analisis lebih lanjut menyimpulkan bahwa tidak terdapat perbedaan yang bermakna rerata kemampuan fungsional komunikasi antara kelompok kontrol dengan intervensi.

Tabel 2 menjelaskan rerata depresi pada kelompok kontrol adalah 9,64 dan pada kelompok intervensi adalah 8,30. Analisis lebih lanjut menyimpulkan terdapat perbedaan yang bermakna rerata depresi antara kelompok kontrol dan intervensi $(\mathrm{p}=0,022)$.

Hasil uji pengaruh faktor-faktor perancu terhadap kemampuan fungsional komunikasi dan depresi (umur, jenis kelamin, frekuensi serangan stroke, ketidakmampuan fisik, dan dukungan keluarga) pada pasien stroke dengan afasia motorik yang diberikan komunikasi dengan AAC memperoleh kesimpulan bahwa secara garis besar faktorfaktor perancu tidak berpengaruh terhadap kemampuan fungsional komunikasi dan depresi, kecuali frekuensi serangan stroke berpengaruh terhadap depresi $(\mathrm{p}=0,048)$.

Tabel 1. Perbedaan Kemampuan Fungsional Komunikasi antara Kelompok Kontrol dan Intervensi Pasien Afasia Motorik

\begin{tabular}{lccccccc}
\hline \multicolumn{1}{c}{ Variabel } & $\mathbf{n}$ & Mean & SD & SE & T & $\begin{array}{c}\text { Mean Diff } \\
\mathbf{9 5 \%}\end{array}$ & p \\
\hline $\begin{array}{l}\text { Kemampuan Fungsional Komunikasi } \\
\text { Kontrol }\end{array}$ & 11 & 10,64 & 1,748 & 0,527 & & $-0,464$ & 0,542 \\
Intervensi & 10 & 11,10 & 1,663 & 0,526 & $-0,621$ & $-2,026-1,099$ \\
\hline
\end{tabular}

Tabel 2. Perbedaan Depresi antara Kelompok Kontrol dan Kelompok Intervensi Pasien Afasia Motorik

\begin{tabular}{|c|c|c|c|c|c|c|c|}
\hline Variabel & $\mathbf{n}$ & Mean & SD & SE & $\mathbf{T}$ & $\begin{array}{l}\text { Mean Diff } \\
95 \%\end{array}$ & $\mathbf{p}$ \\
\hline \multicolumn{8}{|l|}{ Depresi } \\
\hline Kontrol & 11 & 9,64 & 1,1 & 0,388 & \multirow[b]{2}{*}{2,491} & 1,336 & \multirow[b]{2}{*}{$0,022 *$} \\
\hline Intervensi & 10 & 8,30 & 1,160 & 0,367 & & $0,213-2,459$ & \\
\hline
\end{tabular}

*signifikan pada $\alpha=0,05$ 


\section{Pembahasan}

Hasil penelitian tentang pengaruh pemberian AAC terhadap kemampuan fungsional komunikasi dan depresi pada pasien stroke dengan afasia motorik antara kelompok kontrol dan intervensi menunjukkan tidak terdapat perbedaan yang bermakna terhadap kemampuan fungsional komur nikasi, namun terdapat perbedaan yang bermakna terhadap depresi sesudah diberikan AAC pada pasien stroke dengan afasia motorik. Hasil analisis variabel perancu didapatkan frekuensi serangan stroke berhubungan dengan depresi.

Hasil penelitian terhadap kemampuan fungsional komunikasi menjadi tidak signifikan. Hal ini dapat disebabkan karena latihan komunikasi yang dilakukan terlalu singkat hanya 10 hari, sehingga tidak maksimal untuk memperbaiki kemampuan fungsional komunikasi pada semua subjek penelitian karena berat stroke dan derajat keparahan afasia subjek penelitian bervariasi dan terdapat variasi pada setiap individu dalam hal waktu pemulihan. Faktor lain, seperti gangguan kognitif, motivasi pasien juga memengaruhi kemampuan fungsional komunikasi pasien.

Sementara hasil penelitian terhadap depresi memberikan pengaruh yang signifikan pada pasien stroke dengan afasia motorik. Nilai depresi pada kelompok kontrol adalah 9,64 dan kelompok intervensi adalah 8,30. Menurut Benaim, Cailly, Perennou, dan Pelissier (2004), dalam instrumen depresi (ADRS), dikatakan depresi apabila skor pasien sama atau lebih dari 9.

Penggunaan alat bantu visual seperti gambar, tulisan dengan beberapa kata kunci, alat tulis dapat memfasilitasi pemahaman dan ekspresi pasien afasia (Clarkson, 2010). Hal ini sejalan dengan pendapat Kusumoputro (1992) bahwa efektifitas terapi afasia akan meningkat jika latihan menggunakan bentuk stimulus audio dalam bentuk musik dan stimulus visual dalam bentuk gambar-gambar serta lukisan. Sedangkan mengajak pasien bercakap-cakap merupakan terapi dengan pendekatan strategi komunikasi untuk mengembangkan kemampuan komunikasi (Kusumoputro, 1992).

Terapi intonasi lagu dapat digunakan pada pasien afasia dengan kemampuan ekspresi verbal minim (Kusumoputro, 1992; Wirawan, 2009). Pemberian stimulasi melalui lagu, menyanyikan, dan menyuarakan lagu sebelum pasien sakit akan lebih bermanfaat dengan memfungsikan hemisfer kanan karena hemisfer kiri (dominan) mengalami kerusakan. Selain itu musik juga dapat digunakan pasien depresi untuk mengekspresikan emosinya, sehingga dapat mengurangi depresi paska stroke (American Music Association, 2005).

Hasil penelitian ini setelah diberikan AAC pada kelompok intervensi ditemukan penurunan nilai depresi. Berdasarkan hasil pengamatan pasien mampu mengkomunikasikan kebutuhan melalui pemberian buku komunikasi dan objek yang ada disekitar ruangan dengan menunjukkan gambar, sehingga pasien dapat berinteraksi dengan keluarga dan petugas kesehatan.

Menurut hasil penelitian Finke, Light, dan Kitko (2008) bahwa komunikasi dengan AAC dapat membantu perawat berkomunikasi pada pasien yang mengalami keterbatasan komunikasi verbal. Penelitian ini diperkuat oleh hasil penelitian (Clarkson 2010) bahwa AAC dapat meningkatkan kemampuan komunikasi pasien, memperbaiki kehidupan seseorang dengan meningkatkan kemandirian dan perkembangan hubungan sosial, sehingga akan memengaruhi kualitas hidup. Hal ini dapat terjadi karena pasien yang menggunakan AAC pada umumnya memiliki kepuasan dalam hubungan dengan keluarga, teman, dan aktivitas hidup yang menyenangkan.

Jumlah serangan stroke akan berpengaruh terhadap kerusakan otak lebih luas, sehingga dapat memengaruhi wicara dan bahasa. Menurut pendapat Silbernagl dan Lang (2007) bahwa manifestasi klinis stroke ditentukan berdasarkan area serebri yang terkena. Walaupun frekuensi serangan stroke terjadi satu kali, namun bila stroke mengenai lobus frontalis pada hemisfer kiri dominan, kemungkinan pasien akan mengalami afasia dan gangguan mood. Menurut hasil penelitian 
Lee, et al., (2009) bahwa lesi pada hemisfer kiri lebih sering menyebabkan depresi daripada lesi hemisfer kanan dan lebih berat jika lesi mendekati lobus frontal kiri.

Keterbatasan dalam penelitian ini subjek penelitian tidak sesuai dengan target penelitian, karena beberapa responden mengalami drop out. Waktu latihan selama 10 hari tergolong singkat, sehingga tidak maksimal untuk memperbaiki kemampuan komunikasi karena responden memiliki berat stroke dan derajat keparahan afasia yang bervariasi dalam hal waktu pemulihan bicara. Selain itu instrumen yang digunakan untuk menilai kemampuan fungsional komunikasi dan depresi ini walaupun sudah dilakukan interrater, tetapi pada instrumen kemampuan fungsional komunikasi masih membutuhkan acuan/alat yang membuat penilaian menjadi lebih objektif diantara peneliti dan asisten peneliti. Untuk instrumen penilaian depresi, tidak semuanya dilakukan observasi dan ada beberapa item observasi yang perlu dikembangkan agar penilaian observasi lebih objektif.

\section{Kesimpulan}

Penelitian ini membuktikan bahwa tidak adanya perbedaaan yang bermakna terhadap kemampuan fungsional komunikasi sesudah diberi komunikasi dengan AAC. Pada pasien depresi terdapat perbedaan yang bermakna sesudah diberi komunikasi dengan AAC di tiga RSUD Jawa Barat. Hasil penelitian dapat disimpulkan bahwa pemberian komunikasi dengan AAC berpengaruh secara bermakna terhadap depresi pada pasien stroke dengan afasia motorik.

Pemberian komunikasi dengan AAC dapat digunakan sebagai salah satu intervensi keperawatan memfasilitasi komunikasi pasien afasia motorik, seperti papan gambar/buku komunikasi, majalah, foto, musik/lagu, dan alat tulis untuk menurunkan depresi pada pasien afasia motorik. Selain perawat, keterlibatan keluarga juga merupakan salah satu bentuk dukungan yang diperlukan dalam pelaksanaan latihan komunikasi, baik selama di rumah sakit ataupun di rumah.
Penelitian selanjutnya perlu membuat penelitian sejenis yang menilai kemampuan fungsional komunikasi dengan memperhatikan tingkat keparahan afasia, luas, lokasi lesi, dan lama waktu pemberian latihan. Mengembangkan alat ukur untuk penilaian kemampuan fungsional komunikasi serta mengembangkan instrumen observasi depresi pada afasia (PY, RM, AR)

\section{Referensi}

Ackley, B.J. \& Ladwig, G.B. (2011). Nursing diagnosis handbook: An evidence based guide to planning care (9th Ed.). St. Louis: Mosby Elseiver.

American Music Association (2005). Music therapy. Diperoleh dari http://www. musictherapy.org.

Amir, N. (2005). Depresi: Aspek neurobiologi diagnosis dan tatalaksana. Jakarta: Balai Penerbit FK UI.

Bakheit, Shaw, S., Barret, L., Wood, J., Carrington, S., Griffith, S., Searle, K., \& Koutsi, F. (2007). A prospective, randomized, parallel group, controlled study of the effect of intensity of speech and language therapy on early recovery from post stroke aphasia. Clinical Rehabilitation, 21(10), 885-894.

Benain, C., Cailly, B., Perennou, D., \& Pelissier, J. (2004). Validation of the aphasic depression rating scale. Stroke, 35(7), 1692-1696.

Bhogal, S.K., Teasel, R., Foley, N., \& Speechley, M. (2004). Lesion location and poststroke depression: Systematic review of the methodological limitations in the literature. Stroke, 35 (3), 794-802.

Black, J.M., \& Jacob, E.M. (2009). Medical surgical nursing clinical management for positive outcomes (8th Ed.). St. Louis: Elsevier Saunders.

Bulecheck, G.M. \& McCloskey, J.C. (1999). Nursing interventions: Effective nursing treatment (3rd Ed.). Philadelphia: W.B. Saunders Company. 
Caeiro, L., Ferro, J.M., Santos, C.O., \& Luisa, F. (2006). Depression in acute stroke. Journal of Psychiatry Neuroscience, 31(6), 377-383.

Clarkson, K. (2010). Aphasia after stroke enabling communication through speech and language therapy. British Journal of Neuroscience Nursing, 6(5), 227-231.

Dahlin, A.F., Laska, A.C., Larson, J., Wredling., Billing, E., \& Murray, F. (2007). Predictors of life situation among significant others of depresses or aphasia stroke patients. Journal of Clinical Nursing, 17, 1574-1580.

Finke, E.H., Light, J., \& Kitko, L. (2008). A systematic review of the effectiveness of nurse communication with patients with complex communication needs with a focus on the use of augmentative and alternative communication. Journal of Clinical Nursing, 17(16), 21022115 .

Johnson, R.K., Hough, M.S., King, K.A., Vos P., \& Jeffs, T.A. (2008). Functional communication in individual with chronic severe aphasia using augmentative communication. Informa Healthcare, 24(4), 269-280.

Kusumoputro, S. (1992). Afasia: Gangguan berbahasa. Jakarta: Balai Penerbit FKUI.

Lumbantobing, S.M. (2011). Neurologi klinik pemeriksaan fisik dan mental. Jakarta: Balai Penerbit FK UI.

Mulyatsih, E., \& Ahmad, A.A. (2010). Stroke: Petunjuk perawatan pasien pasca stroke di rumah. Jakarta: Balai Penerbit FK UI.

NANDA International. (2011). Diagnosis keperawatan: Definisi dan klasifikasi 2009
2011 (Sumarwati dkk, Penerj). Jakarta: EGC. Buku asli diterbitkan 2002.

Price, S.A., \& Wilson, L.M. (2006). Patofisiologi: Konsep klinis proses-proses penyakit (Edisi ke 6). Terjemahan oleh: Pendit, Hartanto, H, Wulansaei, P \& Kurniangsih. Jakarta: EGC. Buku asli diterbitkan 2003.

Rasyid, A., \& Soertidewi, L. (2007). Unit stroke. Manajemen stroke secara komprehensif. Jakarta: Balai Penerbit FK UI.

Salter, K., Jutai, J., Foley, N., Hellings, C., \& Teasell, R. (2006). Identification of aphasia poststroke: A review screening assesment tools. Brain injury, 20(6), 559-568.

Schub, E., \& Caple, C. (2010). Stroke complication: Post stroke depression. California: Cinahl Information System.

Silbernagl, S., \& Lang, F. (2007). Teks dan atlas berwarna patofisiologi. (Iwan S. \& Iqbal M., Penerj). Jakarta: EGC.

Smeltzer, S.C., Bare, B.G., Hinkle, J.L., \& Cheever, K.H. (2010). Brunner \& Suddarth's textbook of medical surgical nursing (12th Ed.). Philadelphia: Lippincott Williams \& Wilkins.

Thomas, S.A., \& Lincoln, N.B. (2008). Predictors of emotional distress after stroke. Journal of the American Heart Association, 39, 1240-1245.

Wirawan, R.P. (2009). Rehabilitasi stroke pada pelayanan kesehatan primer. Majalah Kedokteran Indonesia, 59(2), 61-71.

Yastroki (2011). Stroke penyebab kematian urutan pertama di rumah sakit di Indonesia. Diperoleh dari http://www.yastroki.or.id. 